\title{
All-trans-retinoic acid-induced pseudotumor cerebri in acute promyelocytic leukemia
}

\author{
T. M. Anoop, Nidhi Jain, Sreejith G. Nair, Geetha Narayanan \\ Department of Medical Oncology, Regional Cancer Centre, Thiruvananthapuram, Kerala, India
}

\section{ABSTRACT}

All-trans-retinoic acid is an integral part in the treatment strategy of acute promyelocytic leukemia (APL). Here we describe a case of pseudotumor cerebri associated with all-trans-retinoic acid (ATRA) during the induction therapy in an adult with acute promyelocytic leukemia (APL).

Key words: Pseudotumor cerebri, acute promyelocytic leukemia, all-trans retinoic acid

\section{Introduction}

Pseudotumor cerebri (PTC) or Idiopathic intracranial hypertension $(\mathrm{IIH})$ is a disorder of elevated intracranial pressure (ICP) without any evidence of infection, vascular abnormality, space occupying lesion, hydrocephalus or alteration of consciousness. ${ }^{[1]}$ All-trans-retinoic acid (ATRA) has been widely used in the treatment of acute promyelocytic leukemia (APL). ${ }^{[2]}$

Cases of pseudotumor cerebri associated with all-trans-retinoic acid treatment in acute promyelocytic leukemia (APL) have been frequently described in pediatric patients. ${ }^{[3]}$ But it is rare in adults.

\section{Case Report}

A 25-year-old female patient presented to our clinic with fever and bleeding gums of three weeks duration. The clinical examination was normal except for a body temperature of $38.5^{\circ} \mathrm{C}$. Systemic examination revealed no abnormality.

\begin{tabular}{|l|l|}
\hline \multicolumn{2}{|c|}{ Access this article online } \\
\hline Quick Response Code: & Website: \\
\hline & www.ruralneuropractice.com \\
\cline { 2 - 2 } & \\
\hline & \\
\hline
\end{tabular}

Hematological investigations showed hemoglobin of $10.7 \mathrm{~g} / \mathrm{dl}$, platelet count $200000 / \mathrm{mm}^{3}$; white blood cell count of $2900 / \mathrm{mm}^{3}$, differential count $30 \%$ blast cells, $6 \%$ neutrophils, $64 \%$ lymphocytes. Coagulation profile was normal. D-dimer was $10000 \mathrm{ng} / \mathrm{ml}$. Serum biochemistry showed lactate dehydrogenase $566 \mathrm{U} / \mathrm{L}$, peripheral smear showed normocytic normochromic anemia, reduced total count with predominant lymphocytes with atypical cells and adequate platelet count. Bone marrow examination showed $84 \%$ blasts which were peroxidase positive with moderate cytoplasm indented to bilobed nuclei with immature chromatin. Flow cytometry was suggestive of acute myeloid leukemia - M3 with CD13, CD33, CD64, CD117, CD45 positivity and negative HLA DR. Real time PCR (Polymerase Chain Reaction) qualitative analysis revealed the presence of typical fusion transcript PML-RARa (bcr1type) in the cells. Chromosomal analysis carried out using bone marrow showed 50\% with 46XX; t $(15 ; 17)$ and 50\% with 46XX. Detection of translocation $t(15 ; 17)$ by FISH using bone marrow showed PML-RARA fusion signal in $90 \%$ of interphase cells.

The patient was started on treatment with ATRA $45 \mathrm{mg} / \mathrm{m}^{2}$ p.o. $(80 \mathrm{mg} /$ day) plus daunorubicin $100 \mathrm{mg} /$ day for four days. After three weeks of induction chemotherapy, the patient started complaining of headache and diplopia. Neurological examination was non contributory. Fundus examination showed bilateral papilledema. Magnetic resonance imaging of the brain was normal. Cerebro spinal fluid (CSF) analysis was normal except for an elevated CSF pressure. Thus a diagnosis of PTC was

\footnotetext{
Address for correspondence:

Dr. T. M. Anoop, Department of Medical Oncology, Regional Cancer Centre, Thiruvananthapuram, Kerala - 695011 , India.

E-mail: dranooptm@yahoo.co.in
} 
Table 1: Details of previously reported cases of PTC after ATRA for APML in the literature

\begin{tabular}{|c|c|c|c|c|c|c|c|c|}
\hline Authors & $\begin{array}{c}\text { Patients } \\
\text { no. }\end{array}$ & $\begin{array}{c}\text { Age } \\
\text { (years) }\end{array}$ & Sex & $\begin{array}{c}\text { Dose of } \\
\text { ATRA given }\end{array}$ & $\begin{array}{c}\text { Day of onset } \\
\text { of PTC }\end{array}$ & $\begin{array}{l}\text { Outcome } \\
\text { of PTC }\end{array}$ & $\begin{array}{c}\text { Overall } \\
\text { outcome }\end{array}$ & Death \\
\hline Colucciello et al..10] & 1 & 30 & $\mathrm{M}$ & $45 \mathrm{mg} / \mathrm{m}^{2} / \mathrm{d}$ & 2 weeks & Resolved & CR & Nil \\
\hline HY Chen et al. ${ }^{[11]}$ & 1 & 17 & $\mathrm{~F}$ & $45 \mathrm{mg} / \mathrm{m}^{2} / \mathrm{d}$ & 6 weeks & Resolved & $\mathrm{CR}$ & Nil \\
\hline Tanaka T et al. ${ }^{[12]}$ & 1 & 21 & $\mathrm{~F}$ & $45 \mathrm{mg} / \mathrm{m}^{2} / \mathrm{d}$ & 11 days & Resolved & $\mathrm{CR}$ & Nil \\
\hline Tiamkao et al. ${ }^{[13]}$ & 1 & 35 & M & 60 mg/d & 2 Weeks & Resolved & CR & Nil \\
\hline Visani G et al. ${ }^{[8]}$ & 1 & 16 & $M$ & $80 \mathrm{mg} / \mathrm{d}$ & 31 days & Resolved & $\mathrm{CR}$ & Nil \\
\hline Vanier et al. ${ }^{[14]}$ & 1 & 4 & $M$ & $45 \mathrm{mg} / \mathrm{m}^{2} / \mathrm{d}$ & 21 days & Resolved & $\mathrm{CR}$ & Nil \\
\hline Naithani $\mathrm{R}$ et al. ${ }^{[15]}$ & 1 & 9 & $M$ & 40 mg/d & 12 days & Resolved & $\mathrm{CR}$ & Nil \\
\hline F Sano et al. ${ }^{[16]}$ & 1 & 18 & $M$ & $45 \mathrm{mg} / \mathrm{m}^{2} / \mathrm{d}$ & 23 days & Resolved & $\mathrm{CR}$ & Nil \\
\hline Naderi S et al. ${ }^{[17]}$ & 1 & 20 & $\mathrm{~F}$ & 80 mg/d & 10 days & Resolved & CR & Nil \\
\hline
\end{tabular}

CR: Complete remission, PTC: Pseudo tumor cerebri, ATRA: All trans retinoic acid, APML: Acute promyelocytic leukemia

made. ATRA was stopped and the patient was started on anti cerebral edema measures and steroids. Headache and diplopia subsided in two weeks. ATRA was restarted after one week. The patient achieved complete remission (CR) after induction chemotherapy without any neurological sequela.

\section{Discussion}

All-trans retinoic acid (ATRA) is used as differentiation therapy for acute promyelocytic leukemia (APL). Even though, ATRA is a well tolerated drug, some patients may develop complications like dry skin, retinoic acid syndrome, hypertriglyceridemia, sweet's syndrome, hyperleukocytosis, and rarely myositis. ${ }^{[-6]}$ The pathogenesis of ATRA-induced PTC is less understood. The mechanism of neurotoxicity is thought to be similar to the pathogenesis of hypervitaminosis A. At higher doses of ATRA, retinoids enhances the production of CSF and alters the lipid constituents of arachnoid villi, disrupting the normal transport system and impending the absorption of CSF at arachnoid villi. Warner et al. reported that CSF retinol levels were higher in patients with idiopathic intracranial hypertension (IIH) than in the subjects without $\mathrm{IIH} .{ }^{[7]}$ A progressive age-related reduction of RAR expression in the central nervous system has also been postulated as a reason for less chance of PTC in the adult APL compare to the children. ${ }^{[8]}$

Even though hallmark of PTC or IIH is papilledema, it can also occur in the absence of papilledema. MR imaging of the optic nerves and pituitary gland may provide important clues like flattening of the posterior sclera, vertical tortuosity and elongation of the optic nerve, distension of the perioptic subarachnoid space, compressed pituitary gland or empty sella. ${ }^{[9]}$

Table 1 shows the details of previously reported cases of PTC after ATRA for APML in the literature. Most cases were reported during the early 2-3 weeks of initiation of
ATRA. Mortality was seen in none of the cases. There was no neurological sequela. This case highlights the possibility of pseudotumor cerebri while on therapy with ATRA even in the adult APML. A strong clinical judgment is necessary to stop ATRA at the onset of neurotoxicity and reinstitute ATRA at the right time to attain clinical remission.

\section{References}

1. Friedman DI, Jacobson DM. Diagnostic criteria for idiopathic intracranial hypertension. Neurology 2002;59:1492-5.

2. Degos L, Dombret H, Chomienne C, Daniel MT, Micléa JM, Chastang C, et al. All-trans-retinoic acid as adifferentiating agent in the treatment of acute promyelocytic leukemia. Blood 1995;85:2643-53.

3. Mahmoud HH, Hurwitz CA, Roberts WM, Santana VM, Ribeiro RC, Krance RA. Tretinoin toxicity in children with acute promyelocytic leukaemia. Lancet 1993;342:1394-5.

4. Hatake K, Uwai M, Ohtsuki T, Tomizuka H, Izumi T, Yoshida M, et al. Rare but important adverse effects of all-trans retinoic acid in acute promyelocytic leukemia and their management. Int J Hematol 1997;66:13-9.

5. Tomas JF, Escudero A, Fernandez-Ranada JM. All-trans retinoic acid treatment and Sweet Syndrome. Leukemia 1994;8:1596.

6. Citak FE, Ezer U, Akkaya E, Ozbulbul N, Bahce M, Kurekci AE. AllTrans-Retinoic acid-induced myositis in a child with acute promyelocytic leukemia. Haematologica 2006;91:e97-9.

7. Warner JE, Bernstein PS, Yemelyanov A, Alder SC, Farnsworth ST, Digre KB. Vitamin A in the cerebrospinal fluid of patients with and without idiopathic intracranial hypertension. Ann Neurol 2002;52:647-50.

8. Visani G, Bontempo G, Manfroi S, Pazzaglia A, D’Alessandro R, Tura S. All-trans-retinoic acid and pseudotumor cerebri in a young adult with acute promyelocytic leukemia: A possible disease association. Haematologica 1996;81:152-4.

9. Suzuki H, Takanashi J, Kobayashi K, Nagasawa K, Tashima K, Kohno Y. MR imaging of idiopathic intracranial hypertension. AJNR Am J Neuroradiol 2001;22:196-9.

10. Colucciello M. Pseudotumor cerebri induced by all-trans retinoic acid treatment of acute promyelocytic leukemia. Arch Ophthalmol 2003;121:1064-5.

11. Chen HY, Tsai RK, Huang SM. ATRA-induced pseudotumour cerebrione case report. Kaohsiung J Med Sci 1998;14:58-60.

12. Tanaka T, Akifuji Y, Mori M, Ueki J, Nakamoto S. Intracranial hypertension in a patient with acute promyelocytic leukemia treated with all-trans retinoic acid. Rinsho Ketsueki 1997;38:47-51.

13. Tiamkao S, Sirijirachai C. Pseudotumor cerebri caused by all-transretinoic acid: A case report. J Med Assoc Thai 2000;83:1420-3.

14. Vanier KL, Mattiussi AJ, Johnston DL. Interaction of all-trans-retinoic acid with fluconazole in acute promyelocytic leukemia. J Pediatr Hematol Oncol 2003;25:403-4. 
15. Naithani R, Kumar R, Mishra P. Pseudotumor cerebri in a child in early phase of induction therapy for APL with ATRA Indian J Pediatr 2009;76:439-40.

16. Sano F, Tsuji K, Kunika N, Takeuchi T, Oyama K, Hasegawa S, et al. Pseudotumor cerebri in a patient with acute promyelocytic leukemia during treatment with all-trans retinoic acid. Intern Med 1998;37:546-9.

17. Naderi S, Nukala S, Marruenda F, Kudarvalli P, Koduri PR. Pseudotumour cerebri in acute promyelocytic leukemia: Improvement despite continued ATRA therapy. Ann Hematol 1999;78:333-4.

How to cite this article: Anoop TM, Jain N, Nair SG, Narayanan G All-trans-retinoic acid-induced pseudotumor cerebri in acute promyelocytic leukemia. J Neurosci Rural Pract 2014;5:273-5.

Source of Support: Nil. Conflict of Interest: None declared.

\section{New features on the journal's website}

\section{Optimized content for mobile and hand-held devices}

HTML pages have been optimized of mobile and other hand-held devices (such as iPad, Kindle, iPod) for faster browsing speed.

Click on [Mobile Full text] from Table of Contents page.

This is simple HTML version for faster download on mobiles (if viewed on desktop, it will be automatically redirected to full HTML version)

\section{E-Pub for hand-held devices}

EPUB is an open e-book standard recommended by The International Digital Publishing Forum which is designed for reflowable content i.e. the text display can be optimized for a particular display device.

Click on [EPub] from Table of Contents page.

There are various e-Pub readers such as for Windows: Digital Editions, OS X: Calibre/Bookworm, iPhone/iPod Touch/iPad: Stanza, and Linux: Calibre/Bookworm.

\section{E-Book for desktop}

One can also see the entire issue as printed here in a 'flip book' version on desktops.

Links are available from Current Issue as well as Archives pages.

Click on View as eBook 